\title{
LA ESTÉTICA FÍLMICA DE HENRI AGEL COMO UNA TEORÍA DE LA CREACIÓN Y LA RECEPCIÓN
}

\author{
Francisco A. Zurian: Universitat de València (España)
}

\begin{abstract}
Todos los seres humanos que no están satisfechos de la vida y que han reprimido ciertas pasiones, ciertas necesidades, ciertos deseos, encuentran sobre la pantalla el milagro, el mito. Es (...) más excitante que la vida cotidiana ${ }^{1}$
\end{abstract}

\begin{abstract}
Sea por esta razón o por otras, lo cierto es que los medios audiovisuales se han convertido en un acontecimiento popular y en muchos casos el único acceso de la gente a un poco de arte y cultura. Tal vez una de las diferencias con respecto a situaciones pasadas sea el papel cada vez más preponderante que se les otorga a los realizadores. Una vez implantado el consumo audiovisual desde la intimidad del hogar el espectador que desea contemplar una obra cinematográfica con ánimo de obtener una experiencia estética, recurre, cada vez más, a un nuevo universo fílmico, constituido por realizadores "de calidad" que aseguran en sus obras un juego predominante de la artisticidad como criterio de valor frente a la comercialidad, didactismo o entretenimiento.
\end{abstract}

\section{Una teoría estética de la creación: la genialidad del autor}

El teórico francés Henri Agel siempre ha abogado por la valoración de la labor del director, en cuanto que reconoce al director de la película como verdadero guía y artífice de la historia que nos presenta ${ }^{2}$. En este sentido también es de notar que la pretensión ageliana es constituir una teoría estética que sea una auténtica teoría cósmica del cine que entiende el "alma del cine" como algo que apunta a la interioridad psicológica del individuo, debiendo conseguir que el espectador se convierta en un receptor reflexivo (en lucha permanente a su inclinación a la pasividad) de la obra cinematográfica. El realizador es el encargado de dar forma a la historia en la película. Como todo artista lo que el director desea es lograr una construcción plástica interesante y contar una historia de acuerdo a su sensibilidad, es decir, pretende no solamente contar una historia sino, también, hacer arte contando esa historia.

\footnotetext{
1 AGEL, Henri: "El cine, nueva dimensión" en VV.AA. Cine, educadores y educandos, Madrid, Sociedad de Educación Atenas, 1961, p. 18.

2 Cfr. ZURIAN, Francisco A.: “Entrevista con Henri Agel: Por una teoría del cine” en Film-Historia, Vol. I, no 1, 1991, p. 41 y ZURIAN, Francisco A.: "Lo real, lo imaginario y lo insinuado. Notas en torno a Henri Agel" en Quaderns de Filosofia $i$ Ciència, nn. 13-14, 1988, p. 171. Como ejemplo se puede citar: "[Existe una] Presencia constantemente experimentada del demiurgo -esto es, del director- en la elección de encuadres, ángulos de toma de vistas, iluminación, montaje, representación de los actores, etc." (AGEL, Henri: El cine. Bilbao, Desclée de Brouwer, 1957, pp. 133; la cursiva es nuestra).
} 
El primero de los objetivos es generalmente consciente. El segundo quizá sea de orden intuitivo, aun en los realizadores más rigurosos. Se puede aplicar a todos el texto tan importante de Gide en Paludes: "Si supiéramos lo que queremos decir, no sabríamos si realmente no decimos más que eso... lo que sobre todo me interesa (en una obra), es lo que he puesto sin saberlo, esta parte del inconsciente que desearía llamar la parte de Dios... Esperemos del público la revelación de nuestras obras"'De ahí que, normalmente, resulten bastante vanas, decepcionantes e ineficaces, las entrevistas a los realizadores preguntándoles el sentido de su obra o lo que en ella han querido expresar. Hay que dejar abierta la posibilidad de una multitud de sentidos, los hubiera querido expresar o no el realizador. Lo cual no va en detrimento del papel del realizador pues es, desde todo punto de vista, fundamental. La misma historia resultará totalmente distinta contada por diferentes realizadores (cada uno con su propio universo de valores y con su propia sensibilidad).

La misma historia contada con otros encuadres y con una planificación diferente, tendría otro significado. La adaptación de una novela puede enriquecerse con una gama de matices imprevistos, si el que lleva el libro a la pantalla escoge tal forma de lenguaje que no estaba necesariamente implicada en el contenido de la obra. Así ocurre en El río, de Rumer Goden, llevado a la pantalla por Renoir; como también en Le journal d'un curé de campagne, adaptado por Robert Bresson.

La originalidad de la composición, el desarrollo del film, la predominancia de planos (...), en una palabra, la construcción plástica, proviene, como la expresión cinematográfica, de una meditación o de un pensamiento interior. Estudiar [a los realizadores y a sus obras] (...) es entrar en la intimidad de estos poetas, de estos soñadores ${ }^{4}$.

De ahí que, para Agel, todo análisis de una película debería comenzar siempre con un riguroso análisis del estilo puesto que la especificidad y los caracteres esenciales del lenguaje de un realizador proporcionan los grandes trazos de la fisonomía de la obra5.

Un auténtico director cinematográfico, y con más razón un autor de películas digno de este nombre, tiene tres preocupaciones, al menos, que disociamos por necesidades de análisis, pero que son sentidas por el director como componiendo un todo:

1. ${ }^{\text {a }}$ Contar bien una historia.

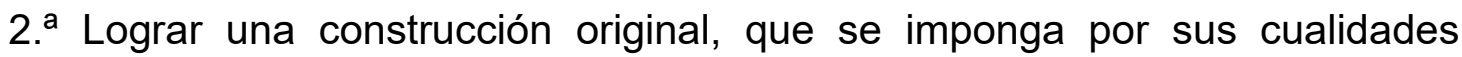

3

AGEL, Henri y AYFRE, Amédée: Cine y personalidad, Madrid, Rialp, 1963, p. 74.

4 AGEL, Henri y AYFRE, Amédée: Cine y personalidad, Madrid, Rialp, 1963, pp. 75-76.

5 De ahí que Agel afirme que "mi teoría está basada en la escritura y el estilo del film" ("Entrevista con Henri Agel: Por una teoría del cine" en Film-Historia, Vol. I, no 1, 1991, p. 38). 
plásticas y dramáticas.

3. " Expresar un tema eterno, un mito, una confidencia, una profesión de fe." 6

Pero esto debemos hacerlo con cuidado para no caer en el paroxismo de un análisis tal que termine por anular la obra. Por el contrario el análisis "debe partir de la simpatía para volver a ella"7. esto, además, tiene la ventaja de permitir distinguir a los realizadores-autores de los estilistas, a los creadores de los artesanos.

Hemos visto que los auténticos creadores de films raramente conocen el pleno significado de su obra. Y que esta obra es infinitamente modelable y sin cesar se expande en la conciencia de los espectadores avisados (...). Hacer notar que queda, por concienzuda que sea la investigación, una parte de sombra, hacer entender que es propio de una obra saturada y viva encerrar múltiples y a menudo contradictorios ecos [que] se sustraen de una elucidación racional y se ramifican a medida que nos aproximamos a ellos ${ }^{8}$.

El rol del director cinematográfico es realizar una obra en la que él transmite un mensaje -o mensajes-, consiguiendo, además, que la imagen adquiera otros muchos sentidos ignorados por el mismo autor. De este modo el rol del espectador será la interpretación del sentido (o sentidos) que la imagen porta en sí misma, aún sentidos ignorados por el propio autor.

Desde el momento en que se admite que el autor, lejos de limitarse a la evocación más convincente de lo real, se esfuerza, por el contrario, en hacer que esa realidad diga lo que él quiere, es posible que un "film" sea considerado no ya sólo como un ensueño, sino como el desarrollo de un proceso de abstracción ${ }^{9}$

Y esto gracias a que la fluidez de la imagen que escapa a simples encasillamientos, mucho más, por ejemplo, que la palabra. El director, gracias a las técnicas que emplea y a su particular forma de ver lo que desea contar consigue la plasticidad que el cine opera permitiendo, como dice Henri Agel, un verdadero proceso de abstracción que lleve de la imagen a la idea.

El plano cinematográfico no es una superficie opaca, sino un agua recorrida por ligeras brisas que refleja los cambios de sombra y de sol. Por paradójico que pueda parecer, las imágenes de un film no se dan de una vez para siempre. Diez visiones nos dan diez instantáneas con distintos matices. $Y$ en nuestro recuerdo tal secuencia es más ondulante que la gorja de una paloma (...).

Todos los grandes autores del film han jugado, conscientemente o no, con esta propiedad de la imagen, o mejor, no han intentado resolver de manera aristotélica sus ambivalencias profundas; han cristalizado -y la imagen del cristal resulta

\footnotetext{
$6 \quad$ AGEL, Henri: Manual de iniciación cinematográfica, Madrid, Rialp, 1958 (3aed. 1965), p. 32. Como dice Agel, las tres preocupaciones forman un todo, de ahí que la enumeración no sea por un orden valorativo, sino, más bien temporal en su planteamiento.

7 AGEL, Henri y AYFRE, Amédée: Cine y personalidad, Madrid, Rialp, 1963, p 77.

8 AGEL, Henri y AYFRE, Amédée: Cine y personalidad, Madrid, Rialp, 1963, p. 78.

9 AGEL, Henri: El cine. Bilbao, Desclée de Brouwer, 1957, p. 137.
} 
demasiado dura para expresar la fluidez de su trabajo- su complejo afectivo, a través de una imagen cuya densidad se debe a esta complejidad ${ }^{10}$.

Por esta razón es tan importante fijarse inmediatamente en el estilo del realizador puesto que, de esta forma, se conseguirá descubrir antes y mejor el universo que esconde y se estará en disposición de, además, conseguir otros sentidos que permanecían ocultos, incluso para el autor. La forma de contar, la forma de realizar, en definitiva una película, no es cuestión sin importancia, como no lo es en ninguna de las artes, puesto la artisticidad radica en la forma no en el contenido. El contenido de las películas, por ejemplo, sobre Juan de Arco serán en todas las películas el mismo (la vida Juana o determinado suceso de su vida), lo que variará será la forma de expresar ese contenido -esa historia- y eso, precisamente, es lo que hace de unas de esas películas verdaderas obras de arte y, de otras, meras "producciones" audiovisuales.

En la pantalla, la escritura escogida por un autor no es jamás gratuita (apenas existen estilistas puros); y (...) la intuición, el pensamiento o el mensaje del creador no puede darse plenamente sino desarrollados bajo ciertas formas y estructuras, que son la expresión misma o, si se quiere, la encarnación de este movimiento del espíritu ${ }^{11}$.

En el fondo lo que late en la obra ageliana es una "teoría sobre la genialidad" como teoría de la creación artística cinematográfica ${ }^{12}$. El realizador es el encargado de transcribir el guión, la historia o el hecho a imágenes de una forma genial. Dependerá de él, de su saber hacer y de su especial sentido artístico (de verdadero maestro cinematográfico), que la obra cinematográfica alcance la meta propuesta. Es, por ello, por lo que la definimos como una teoría del genio.

¿Cuántas veces habrá que decir que la unidad de inspiración y de expresión es fundamental en estas empresas? ${ }^{13}$.

Es decir, Agel une "genio" con "profesionalidad", con saber hacer; se une tener inspiración con tener oficio. No basta una cosa sin la otra. Se deben dar las dos características conjuntamente. Como consecuencia, se demanda del realizador que debe ser lo suficientemente inteligente, tener la suficiente visión y el oficio necesario para saber hacer bien las imágenes de la película, contar bien su historia y transmitir oportunamente su sentido, deberá saber elegir el aspecto particular -histórico, psicológico, social...- que le permitirá poner mejor de relieve su obra.

Dicho todo esto se debe dejar claro que lo que nuestro autor defiende no es una "pseudo-poetización" fácil del cine, entendida ésta como un estilo que, a priori, fomentara el sentimentalismo, la anécdota, el didactismo o el moralismo. Agel huye de esto, él busca una perspectiva más recia en la autenticidad de la imagen sin recursos fáciles a eclosiones sentimentales. No es cosa fácil. Por ello Agel podía

10 AGEL, Henri y AYFRE, Amédée: Cine y personalidad, Madrid, Rialp, 1963, pp. 78-79.

11 AGEL, Henri: Manual de iniciación cinematográfica, Madrid, Rialp, 1958, p. 35.

12 ZURIAN, Francisco A.: "Lo real, lo imaginario y lo insinuado. Notas en torno a Henri Agel” en Quaderns de Filosofia i Ciència, nn. 13-14, 1988, p. 172.

13 AGEL, Henri: El cine y lo sagrado, Madrid, Rialp, 1960, p. 109. 
decir que, a su modo de ver, solamente un tercio (aproximado) de la producción mundial de cine podría ser considerado, con justicia, como tal. ¿Cómo discernirlo? Para ello nos hace falta todavía un paso más, puesto que el juicio supone contemplación y esto nos remite al espectador.

\section{Una teoría de la recepción: el triunfo sobre la pasividad}

Gracias a la conjunción de todos los elementos que confluyen en el hecho cinematográfico, en el espectador se opera un verdadero "proceso de identificación" con todo aquello que sucede en la pantalla, especialmente con los personajes que en ella se suceden. Esto se debe también a que el espectador "va" a la película, normalmente, en estado de completa maleabilidad y se deja "llevar" por su "pasividad"14 y, además con un acceso a la obra peculiar, lo que denominamos aprehensión por simpatía.

El fenómeno cinematográfico es mixtificación, enajenación, violación de las conciencias. El espectador, "victima que consiente y se encanta", se siente obligatoriamente disminuido y envilecido por su participación en el film que desbarata su libertad, deshace su autonomía y hace de él algo inconsciente. Sólo la alerta del espíritu crítico, la costumbre de juzgar el film, de separarse de él para mirarlo con ojos amigables, pero lúcidos y destapados puede operar una sana catarsis, llevando a considerar el film como un objeto de arte o como un mensaje15.

El problema de la "pasividad"16 en el espectador es uno de los asuntos quiciales en cualquier estudio sobre el rol del espectador en la aprehensión del objeto artístico y su conversión en objeto estético; aquí se centra la teoría de la recepción en Agel. Esta teoría se articula en torno a los parámetros de la intuición, la interpretación (búsqueda de sentido) y, específicamente, el triunfo sobre la pasividad, que tiene como colofón la idea clara de educación del espectador para poder sacar "partido" a su visionado. Por eso Agel puede decir que lo que él intenta, al fin y al cabo, no es otra cosa que "poner al público en 'estado de gracia' o de receptibilidad". De facto, para él, "ese es el papel del Cine"17.

La razón última de la importancia de este tema de la pasividad es que la obra es abierta, posee una multitud de posibilidades significativas; si la obra estuviera acabada, si se tratara de una obra "cerrada", la pasividad del espectador no sería ningún problema ya que su actitud podría ser pasiva puesto que lo único que tendría que hacer es conocer la técnica del lenguaje y captar su único y directo mensaje;

Hablar de "pasividad" en un comentario sobre arte puede tener dos posibles lecturas, una positiva y otra más peyorativa. Aquí la hemos utilizado de la segunda forma y, lo que quiere indicar -con Agel- es esa actitud pasiva, nada activa, de ciertos espectadores que más que "visualizar" -contemplar- la película lo único que hacen es "verla", esto es, dejarse envolver por la imagen sin adentrarse, en ningún momento en ella, quedándose en una mera visión epidérmica. Cabe, por el contrario un concepto más positivo, casi sinónimo al de "contemplación", pero al que Agel no se refiere cuando utiliza la expresión "pasividad".

15 AGEL, Henri y AYFRE, Amédée: Cine y personalidad, Madrid, Rialp, 1963, pp. 69-70.

16 Cfr. AGEL, Henri: "La victoire sur la passivité" en HAHN, George (Ed.): Cinéma univers de l'absence? Le sort de la personne dans l'oeuvre filmique, París, P.U.F., 1960, pp. 56-67.

17 ZURIAN, Francisco A.: “Entrevista con Henri Agel: Por una teoría del cine” en Film-Historia, Vol. I, no 1, 1991, p. 41. 
aquí, evidentemente el problema no sería la pasividad sino, más bien, la decodificación del mensaje -directo- de la imagen. Pero como la obra cinematográfica -y, de hecho, cualquier obra de arte- es abierta y no está terminada es decir, aportando un único sentido-, el receptor debe ir adentrándose en ella para intentar ir descubriendo dicha polifonía de sentidos posibles. Por ello, el espectador, no puede quedar al margen, no puede esperar a que le den hechos los sentidos, so pena de perder la posibilidad de contemplar, verdaderamente, la obra.

Siempre hay varias lecturas posibles en una película18. El espectador, en su contemplación activa del objeto cinematográfico -la película-, está haciendo una de esas lecturas (en otro visionado hará otra), por ello, podemos decir que está creando, está haciendo arte sumido en esa contemplación estética de esa obra de arte. Esto es lo que hará exclamar a Steiner que "las mejores lecturas del arte son arte"19. Y son arte porque el espectador es, también, un artista, coautor de la obra.

El problema será conseguir que el espectador sea consciente de esta realidad. Frente a lo fácil de la pasividad -de hundirse en la butaca y dejarse golpear por las imágenes- debe educarse al espectador en orden a conseguir de él una función activa y creadora, que sea capaz de contemplar la realidad profunda de la obra, que sea capaz de desentrañar su "alma". ¿Por qué esta insistencia ageliana en la pasividad? Sin duda hay un factor genérico, que ya hemos visto, la activa actitud de interpretar; pero, además existe también otro factor, de orden circunstancial. Agel quiere ponernos en guardia contra las condiciones materiales en las que se suele dar el visionado cinematográfico y que tan fácilmente inducen a ostentar una actitud pasiva y de dejadez en la contemplación de la obra cinematográfica. Estas condiciones son, por un lado externas (la sala es un lugar oscuro, el espectador se suele situar hundido en su butaca y con su cabeza colocada en un estado de receptividad extrema y de pasividad o, en otro sentido, en la intimidad del propio hogar, en tu propio sofá, en tu propio entorno) y, por otro internas (una pantalla luminosa que llena de luz la oscuridad de la sala por medio de la pantalla que actúa como un enmarcador del haz de colores, la luz artificial que ilumina la imagen y que da más brillo, más relieve y es, por ello, más violenta). Estas características suelen dejar al espectador en un estado de mínimo esfuerzo y, por ello, debe sobreponerse para poder vencer a esa pasividad con-natural a la recepción cinematográfica.

Las escenas, se nos ofrecen con mucha más fuerza, ya que están circunscritas en un pequeño espacio rectangular; (...) por el hecho mismo de estar esta misma escena limitada, localizada y circunscrita sobre un pequeño rectángulo luminoso, adquiere una fuerza, un poder y una agudeza mucho más considerables y nos impresiona, naturalmente de una manera bastante más profunda (...) todos estos elementos reunidos: la localización del objeto en la pantalla, la intensidad de la iluminación, el tamaño del plano y la duración de la imagen, hacen que nos sumerjamos en una verdadera magia (...), en una especie de sortilegio 20.

\footnotetext{
18 Cfr. ZURIAN Francisco A.: “Entrevista con Henri Agel: Por una teoría del cine” en Film-Historia, Vol. I, no 1, 1991, p.

40.

19 STEINER, George: Presencias reales. ¿Hay algo en lo que decimos?, Barcelona, Destino, 1991, p. 29.

20 AGEL, Henri: “El cine, nueva dimensión" en VV.AA. Cine, educadores y educandos, Madrid, Sociedad de Educación Atenas, 1961, p. 19.
} 
Tampoco puede pensarse que vencer la pasividad consiste en una lucha por estar incómodos en el cine. Se trata, más bien, de estar en una actitud receptiva y, para ello, seguramente tendremos que estar atentos a no dejarnos llevar por las imágenes sino tratar de "vivirlas" para, así, encontrarles sus posibles significados. $\mathrm{Ni}$ consiste en ir buscando desesperadamente significados. Una actitud activa no es activismo. La actitud del receptor en la contemplación estética de una obra artística -o no artística, v.g. un paisaje de la naturaleza-, es precisamente eso: contemplación. La contemplación requiere sosiego, entrar en diálogo, en comunión, con lo contemplado, dejarse penetrar, dejarse interpelar, dejarse hablar por la obra. La contemplación, si es verdadera, conlleva un darse de la obra al receptor y un dejarse modelar por él y, viceversa, un darse el receptor a la obra, un dejarse transformar por ella, un enriquecerse con-y-por ella. Existe un verdadero intercambio, una donación, una auténtica, repetimos, comunión.

No es posible, si la contemplación, repito, es auténtica, que después de haber vivido una experiencia estética, seamos exactamente iguales, que no hallamos experimentado ningún crecimiento interior, espiritual, intelectual, emotivo y/o afectivo. Si eso es así es que nuestra contemplación no existe o nuestra humana vida interior es nula. Por el contrario, si ha habido verdadera experiencia estética, "el espectador es diferente"21. Tenemos que luchar, para conseguirlo, no solamente contra nosotros mismos ${ }^{22}$, sino también contra todo el ambiente imperante en el que la ley del mínimo esfuerzo y de la superficialidad rigen con dominio absoluto. Lo cual significa que, la cultura, está inmunizada contra ser auténticamente cultura y el ser humano está inmunizado contra ser plenamente persona. De ahí que una auténtica contemplación nos haga mejores personas ("más" persona), más cultas y, por más cultas, más cultivadas (aunque sin implicaciones directas en ser mejores en un sentido moral o ético). Ese es el trabajo del receptor. Retomando el término de James Joyce, Peter Wollen lo califica de "work in progress" 23 , trabajo continuo, en progreso, que hace que la obra nunca esté terminada, cerrada.

Estamos en el continuo diálogo entre la obra y su receptor que es la contemplación estética. Ya no se va a la contemplación del objeto artístico (es decir, a visionar una película, escuchar una sinfonía, leer un texto, mirar un cuadro...), sino que se va con una actitud pasiva que pretende enfrentarse con un simple mensaje que decodificaremos de forma que nos de una interpretación inmediata. ¿Por qué nuestra cultura es una cultura del audiovisual? Seguramente porque es una cultura de la comodidad, de la búsqueda del placer (o, al menos, del no-esfuerzo) y del gusto por lo rápido (se vive en la pura inmediatez de fines efímeros e irreales, lo que parece concordar con cierta imagen de lo fílmico). En una cultura así, leer supone

\footnotetext{
21 ZURIAN, Francisco A.: “Entrevista con Henri Agel: Por una teoría del cine" en Film-Historia, Vol. I, no 1, 1991, p.

41.

22 La victoria sobre la pasividad es, a fin de cuentas, la victoria sobre la comodidad, sobre la pereza y, especialmente, sobre la pereza mental que, sin duda, es la peor clase de pereza, pues nos hace intelectualmente insensibles y nos expone al nivel epidérmico de las sensaciones, de las apetencias y del mero sentimentalismo, haciéndonos incapaces de practicar una ponderada meditación, encerrándonos en nosotros mismos sin capacidad de apreciar ni "al" otro ni "a lo" otro, consiguiendo que seamos opacos a las emociones $y$, por lo tanto, sin posibilidad de experimentar ni afectos ni sentimientos. La verticalidad propia del ser humano supone la armonía -el equilibrio es virtualidad de la verticalidad- de todo lo que significa ser persona humana: inteligencia, sentidos y voluntad, lo que conlleva siempre, en el plano humano, esfuerzo por armonizar que supone, siempre, esfuerzo por humanizar-nos.
}

23 WOLLEN, Peter: Signs and Meaning in the Cinema, Londres, Thames and Hudson, p. 164. 
demasiado esfuerzo, sobre todo se trata de un esfuerzo mediado; la imagen, por contra, no supone esfuerzo y, en todo caso, se trata de un esfuerzo inmediato. Se prefiere ver una historia en la pantalla que leerla en su libro original, entre otras cosas porque la inversión en la pantalla es de menos de dos horas. Esta actitud, hay que tenerlo claro, mata la cultura y mata las artes, en definitiva mata el desarrollo personal para el que es imprescindible tanto una como las otras. En la verdadera contemplación estética la actitud del espectador debe ser dinámica e innovadora, una actitud de permanente diálogo con la obra y, además, supone, también, una actitud de trabajo, de esfuerzo.

Es claro que una de las grandes bondades del cine es la posibilidad de proporcionar una apertura enorme de un mensaje artístico a un cuantioso número de espectadores. En ese sentido, y no en otro, vale la pena el calificativo de "arte de masas", si por "masas" entendemos una ingente cantidad de potenciales receptores personales, no espectadores anodinos de un artefacto masificante y culturalmente alienante. Esta es la meta de Agel, conseguir que los espectadores de la obra cinematográfica sean receptores atentos y personales, con capacidad de vivencia estética. Para ello, lo primero, como estamos viendo, es despertarlos de la pasividad $\mathrm{y}$, de este modo, conseguir que el espectador interprete lo que en las imágenes se le ofrece dejándose llevar por su intuición, por su afectividad, de manera que se puedan desentrañar la multitud de sentidos que posee la obra, todo un abanico abierto de posibilidades.

El film, cuando es obra de arte, es, como toda obra de arte, capaz de tener varios sentidos; es polivalente, pero no explota sus diversas posibilidades; las bosqueja o las sugiere, y es en el espectador donde, tras de captarlas, han de tener su desarrollo, su evidencia y su florecimiento, que ha rehusado darles el artista24.

Por eso nunca dos percepciones de una misma imagen son iguales, todo lo contrario, cada una encontrará una riqueza nueva, un sentido diferente. $Y$ esa capacidad de "abrirse" de la película en una polifonía de sentidos es, entre otras cosas, la que hará de ella una "gran" película, un buen cine, un cine con alma.

No hay, pues, del film, una comprensión única, como no hay más que una comprensión en una proposición matemática, sino que, recibido y meditado por subjetividades diversas, el film adquiere significaciones diversas, que encubría, sin duda, pero que en él permanecían en potencia. Comprender no es añadir algo al film, sino continuarlo, y continuarlo en su sentido o mejor en uno de sus sentidos. Esta actividad no es gratuita; se ejerce partiendo de la obra y vuelve a la obra. No es, a fin de cuentas, más que una explicación. El espectador se compara con el film, pero lo que compara no es un estado emocional ni un sueño sin trabas, es un yo a la vez abierto y activo, es una vida espiritual ${ }^{25}$.

De todas formas, Agel asegura que no hay que caer en un intelectualismo, puesto que el "proceso esencialmente intelectual (...) no puede ser considerado, en sí 
mismo, como el acceso a un conocimiento espiritual. Esta cerebralización universitaria en sentido estricto- ¿no se arriesga a ser esterilizante?"26. Para nuestro autor el conocimiento, tanto de un poeta, de un pintor o de un músico, no requiere más que cierto número de procedimientos, técnicas y fórmulas, pero solamente se puede llevar a cabo con plenitud cuando el conocimiento se lleva al plano del encuentro, del encuentro directo con la obra y con el autor. de ahí que sería muy importante que el espectador se educara, en principio, para poder "encontrarse" con los realizadores y, de ellos, así, con sus obras. Este encuentro se suele dar, en principio, con la obra -y con sus "héroes"-, después con su realizador, al igual que sucede en la literatura, de los personajes de la obra al autor. Esto conlleva una patente necesidad de rigurosidad en nuestro juicio, pues, muchas veces los héroes cinematográficos pueden ser "huecos":

Toda pedagogía sana del cine comenzará por el descubrimiento de los creadores, que nunca es demasiado pronto para llevarlo a cabo. Pero, en principio, se darán a conocer por los héroes que han creado (...).

Se siente gustoso [el espectador] de compartir sus angustias o descalabros [de los personajes] en aventuras como las de los adolescentes maduros de un Dickens, de Don Quijote o de Robinson Crusoe. A veces, es cierto, el mito se degrada. Surge Tarzán, y con él la pacotilla del supermán exótico. Ha llegado el momento de dar a nuestra iniciación un carácter más riguroso: detrás de Monsieur Hulot está Jacques Tati; como detrás de Nanuk está Flaherty. Los nibelungos es el sueño monumental de Fritz Lang y El acorazado Potemkin, el himno de Eisenstein a la libertad. Detrás de Tarzán o de Ademaï, no hay nada ni nadie 27.

Es, por ello, que el espectador necesita adoptar una postura activa en el visionado de las obras cinematográficas. Esto es del todo evidente para nuestro autor y para casi todos, ahora bien, para un lector actual, lo que puede resultar un tanto sorprendente son las razones que escribía Agel -en tono educativo y moralizante, en un lenguaje y con unos conceptos un tanto obsoletos- cuando señalaba que esa identificación espectador-personaje está especialmente remarcada en el llamado "cine industria" y entre los espectadores menos "cultos", puesto que

Desde el instante en que la oscuridad se hace en la sala, el ser humano olvida a los personajes que están a su alrededor (...); se identifica únicamente con el personaje de la pantalla, vive en una delectación completamente personal con los protagonistas de la pantalla (...). Hay, (...) mezcla de gregarismo y de soledad 28 .

El encuadre realza los elementos de la imagen y, de este modo, la sensación de realidad aumenta al resultarnos mucho más significativos todos los elementos que visualizamos. Esto, sin duda, constituye un hecho muy importante puesto que

\footnotetext{
26 AGEL, Henri y AYFRE, Amédée: Cine y personalidad, Madrid, Rialp, 1963, p. 70.

27 AGEL, Henri y AYFRE, Amédée: Cine y personalidad, Madrid, Rialp, 1963, p. 73.

28 AGEL, Henri: "El cine, nueva dimensión" en VV.AA. Cine, educadores y educandos, Madrid, Sociedad de Educación Atenas, 1961, p. 20.
} 
confiere al cine, también, un valor extremadamente educativo.

La pantalla nos hace ver cosas en las que no nos hubiéramos fijado en la vida, al menos en el mismo grado (...).

El cine, lejos de ser una reproducción del mundo exterior, es más exactamente una transfiguración, o si preferís, una orquestación del mundo exterior. [Pues nos ofrece] una vista del mundo exterior constantemente renovada, constantemente multiplicada y que jamás se repite (...). El nos restituye la realidad que nos rodea con más intensidad y con más intimidad (...).

El cine enseña a gozar, en cierto modo, no sólo de la naturaleza, sino también del mundo cotidiano; (...) llega a transfigurar los objetos más banales ${ }^{29}$.

Y los transfigura en "algo" que se nos presenta como importante en sí mismo: convirtiendo lo cotidiano en algo extraordinario a nuestra vista, descubriéndonos su poesía. por ello, el espectador debe ser verdaderamente receptor y no mero espectador pasivo. Pero la transgresión de lo concreto que Agel propone no es un "vuelo" arbitrario hacia los extramuros de este mundo, sino todo lo contrario, se sitúa plenamente dentro de la realidad pero llegando a la más plena y profunda realidad gracias a que el espectador, convertido en perceptor reflexivo de la obra cinematográfica, ha sido capaz de desentrañarla. Y es que el hecho cinematográfico, como todas las demás artes pero, tal vez, si cabe, de una forma más singular, necesita del espectador que revele lo que la película, en sí, contiene. Una película nunca se acaba de revelar. Además su revelación se produce en el tiempo, de forma temporal, ya que el receptor no tiene a una toda la obra delante de sus ojos, sino que las imágenes fluyen y es él el que debe ir uniendo imagen tras imagen y darle sentido.

De este modo, el rol del espectador es la interpretación del sentido (o sentidos) que la imagen porta gracias al realizador pero, a su vez trascendiéndolo, por la virtualidad de la imagen para adquirir otros muchos sentidos no pensados, siquiera, por el autor. Es por ello que la experiencia y la intuición del espectador serán las únicas capaces de descubrir el sentido pleno del objeto estético, un sentido inalcanzable para un simple análisis lógico. De ahí que el buen espectador deba salir de su pasividad -"triunfar" sobre ella, diría Agel- y convertirse en una persona activa, verdadero intérprete de lo que ve. De este modo consigue el espectador su plena libertad de "vidente" y de "coautor" de la obra que está visionando. El cine no sólo es lo que aparece en la pantalla, requiere de algo, de alguien más bien, fuera de él para cobrar todo su sentido. Requiere del espectador.

La iniciación al cine es, ante todo, una victoria sobre la pasividad: está fundamentalmente por encima de toda arbitraria profilaxis moral. Aprendiendo a descifrar un film (...) conserva su libertad y neutraliza los venenos que pueda contener una imagen.

29 AGEL, Henri: "El cine, nueva dimensión" en VV.AA. Cine, educadores y educandos, Madrid, Sociedad de Educación Atenas, 1961, pp. 22-23. La cursiva es nuestra. 
(...) El sentimiento de redescubrir con ojos nuevos lo que ellos habían asimilado por primera vez de forma un poco ingenua, será para ellos [para los espectadores que se formen] un elemento de equilibrio intelectual y moral. De este modo esta iniciación [es decir, educación cinematográfica] no sólo les preservará de los peligros inherentes al espectáculo -tan frecuentemente señalados como para limitarnos ahora a aludirlos-, sino que favorecerá el desarrollo moral de la persona, lo cual debía ser el primordial empeño de todo educador ${ }^{30}$.

El cine, así entendido, apunta hacia algo "otro" que hay que saber captar, de ahí la necesidad de poner al público en estado de receptibilidad, "gracia" diría nuestro autor. Hay que saber "hacer hablar" al texto audiovisual, para lograr ponerse a su altura, sin intentar reconstruirlo, sin intentar tampoco refutarlo, y es que la escritura es "exterior" a la verdad: sólo la transmite. Con las imágenes, en el caso del cine, se "apunta" a algo, pero siempre se requiere de aquello que ellas representan, esto es, se requiere de un planteamiento, al final, ontológico. Por ello es necesaria una oportuna educación audiovisual, de este modo se podrá aprovechar de verdad la imagen y la realidad que ella nos transmite.

El artista aporta una imagen o serie de imágenes, bellas en sí mismas pero capaces también de consolidad e iniciar nuevas ideas. El crítico (y todo espectador lo es en parte) elabora las ideas latentes en la obra y las vincula con la gran red de ideas que llamamos conocimiento. La imagen sale de la experiencia prelógica y asciende hacia la idea. El crítico apresa la imagen en su ascenso y dibuja sus verdades racionales. Pero (...) el proceso no es hasta aquí completo, porque el crítico, enriquecido con sus ideas, debe entonces someterse nuevamente a la imagen y descender al nivel de la experiencia, dejando que la imagen se hunda en el fluir de la vida interior. El crítico debe seguir a la imagen con una respuesta fresca a la realidad ${ }^{31}$.

La conclusión inmediata que podemos sacar es la necesidad de un "espectador-tipo" que sea reflexivo, capaz de dar prioridad a su propia intuición interpretativa "y es, precisamente, la conjunción de experiencia e intuición la que va a descubrir el sentido pleno del objeto estético, un sentido que revela un mundo oculto para un simple análisis lógico y que culmina en la manifestación de lo trascendental y místico"32.

Como se puede apreciar la trasgresión de lo concreto que Henri Agel propone no es algo meramente subjetivo, al menos eso pretende, sino un conjunto de reflexión, experiencia e intuición que es el que permite descubrir el sentido del artefacto fílmico. ${ }^{33}$

30 AGEL, Henri y AYFRE, Amédée: Cine y personalidad, Madrid, Rialp, 1963, pp. 81-82.

31 ANDREW, Dudley J.: Las principales teorías cinematográficas, Madrid, Rialp (2a ed.aumentada; $1 \underline{a}$ ed. en Barcelona, Gustavo Gili, 1978). p. 295.

32 ZURIAN, Francisco A.: "Lo real, lo imaginario y lo insinuado. Notas en torno a Henri Agel" en Quaderns de Filosofia i Ciència, nn. 13-14, 1988, p. 171.

33 ZURIAN, Francisco A.: “Entrevista con Henri Agel: Por una teoría del cine” en Film-Historia, Vol. I, no 1, 1991, p. 42. 


\section{En busca de una mirada propia: ética y educación}

El nexo que une a realizador y espectador es, para Agel, una visión metafísica, ontológica.

El arte debe dar al espectador, cualquiera que sea su posición metafísica, y al menos durante el tiempo de representación, la ilusión de realidad de lo sagrado, por medio de esa dimensión trascendente que le hemos reconocido. El cine, como el teatro, exige una "creencia como si..., pide un acto de fe que me compromete como espectador ante la escena y no como hombre en el mundo" (...). Dicho de otro modo, es preciso que el espectador dé pruebas de un mínimo de actividad estética e intente penetrar en la obra por los mismos medios que ha empleado el artista ${ }^{34}$.

La implicación metafísica nos conduce decididamente a la "ética de la realización" y a la "ética de la visualización", puesto que ambos, realizador y espectador, deben saber desempeñar bien su rol, esto es, el realizador debe ser un verdadero autor, un verdadero artista que sea capaz de guiar bien una historia y el espectador debe ser capaz de mirar la obra apreciando su(s) sentido(s). Para ambas cosas se necesita, como dice Agel, una mirada limpia, un estado de gracia o, dicho en un lenguaje más normal, una visión ética en su actuar. Gracias a este planteamiento ético -el hombre está invitado al mundo por el arte- el espectador descubre, de verdad, la obra (y la vive). Y el autor es capaz de realizar, auténticamente, una obra artística, que pueda ser un objeto estético. Pero es que, además, de esa necesidad ética en el realizador y en el espectador, es una evidencia que la película en sí misma tiene unas claras y patentes implicaciones morales.

De ahí que veamos cómo la pantalla nos permite volver a encontrar ciertas realidades morales y espirituales no ya en abstracto ni de una manera teórica, sino precisamente partiendo de los hombres y de su medio ambiental. Así, de esta corrección se desprenderán lentamente, insensiblemente, ciertas verdades eternas, verdades que aparecerán entonces como extraídas con su propia ganga, todavía llenas de tierra y de sangre; pero en virtud de ese hecho mismo, el hecho de que aparezcan encarnadas, mezcladas a la toba de la vida, esa verdades son más revelantes, adquieren una autenticidad mayor y más impresionante.

Con todo este bagaje humanístico, la pantalla se convertirá en lugar privilegiado en el que irá a inscribirse todo un sistema de signos intelectuales y morales, que podemos descifrar a través de los mismos elementos del cosmos y de la vida social; signos creados y ordenados de modo que signifiquen lo que corresponde a la visión del mundo entrañada en un artista creador 35 .

Esa visión ética demanda, como decimos, una educación que debería tener tres pilares fundamentales, a saber, la formación técnica, la estética y la moral. La educación sobre las cuestiones más técnicas tiene como finalidad el conocimiento 
del medio audiovisual, sus elementos (la producción, el guión, las propiedades de la imagen y el encuadre, los planos y las secuencias, los movimientos de cámara, los medios de "puntuación", el montaje...) y posibilidades expresivas. La educación estética debe otorgar la suficiente sensibilidad para estar en condiciones de experimentar una vivencia estética, $\mathrm{y}$, además, despertar la mente ante la comprensión del símbolo y las realidades metafísicas. Es el momento del andamiaje más filosófico donde gravitan, también, los planteamientos antropológicos, metodológicos y culturales. Por su parte, la educación ética es la posibilitadora de saber ver con una mirada de estado de "gracia", es decir, con una bondad que descubra el alma del cine.

Al mostrar a los jóvenes cuáles son los elementos fundamentales del lenguaje cinematográfico se liberan en su interior varios mecanismos activos que hasta cierto punto pueden compensar su inicial pasividad de espectadores medios. Con el tiempo, la toma de conciencia de esa peculiaridad artística del "film" les inducirá a exigir del cine obras que respondan a sus medios excepcionales. Más adelante, se les alcanzará que ciertas ideas morales, determinados valores éticos, expresados por la sintaxis fílmica, adquieren un relieve y una densidad notables. Entonces, el cine llegará a ser uno de los elementos fundamentales del humanismo. Incluso se puede afirmar que en cierto modo renovará el humanismo tradicional, dándonos de la condición humana una aprehensión más completa, más exultante y más viva ${ }^{36}$.

Como se puede deducir, fundamentalmente la enseñanza no es histórica, ni consiste en un recordatorio de anécdotas "fílmicas". En primer lugar se trata de enseñar para saber ver. Enseñar para operar, para enfrentarse a las obras cinematográficas. Después ya vendrá otro tipo de educación, más erudita si se quiere, que versará sobre análisis más profundo, escuelas cinematográficas, autores, etc. Para nuestro autor es básico que esa educación se realice en la enseñanza "reglada". Un buen ejemplo es su empeño personal de introducir las clases de cine en los institutos donde trabajó o la publicación de su Manual de iniciación cinematográfica que llevaba el significativo subtítulo de Para clases de bachillerato superior y curso preuniversitario ${ }^{37}$. O su texto, también muy básico, El cine (ya citado) o el todavía más básico Cine, educadores y educandos ${ }^{38}$, o su mismo Le cinéma ses diverses méthodes d'enseignement ${ }^{39}$, con todo no se trata tanto de obras metodológicas y/o pedagógicas como de pequeños manuales de exposición -a nivel más bien sencillo, salvo el último de los citados que se dirige especialmente a universitarios- de cómo entiende Agel el cine.

De este modo, paralelamente a la enseñanza tradicional de las humanidades, que abre el alma de los jóvenes a los valores intelectuales y espirituales, se puede convenir una iniciación al cine que permita a

\footnotetext{
36 AGEL, Henri: El cine. Bilbao, Desclée de Brouwer, 1957, p. 347.

37 AGEL, Henri con Geneviève Agel: Manual de iniciación cinematográfica, Madrid, Rialp, 1958 (3ạed. 1965).

38 VV.AA. Cine, educadores y educandos, Madrid, Sociedad de Educación Atenas, 1961; donde escribe tres capítulos del libro: "El cine, nueva dimensión" (pp. 17-27), "El humanismo cinematográfico" (pp. 63-71) y “El cine-club en el Instituto" (pp. 173-180).

39 AGEL, Henri: Le cinéma ses diverses méthodes d'enseignement, Friburgo, Ed. Université du Fribourg, 1978.
} 
nuestros alumnos descubrir y captar de nuevo esos valores más directamente, incorporándolos a sus vidas con mayor penetración. El resultado se verifica no ya sólo en el plano del cine, que deja de ser un puro divertimiento, para hacerse objeto de cultura y meditación, sino también en el orden de las humanidades, que dejan de ser una materia puramente abstracta y cobran vida gracias al cine ${ }^{40}$.

Aunque para Agel lo ideal sería esta integración en la enseñanza media oficial, no excluye de dicha formación a los jóvenes que no han podido cursarla. De hecho, es evidente, que ellos también están sumidos en la cultura audiovisual. De esta forma se podrían realizar las clases en sus centros de formación profesional o, por medio de casas de cultura, cine-clubs, etc. Además piensa nuestro autor que podría ser muy pedagógico y hacerles alcanzar cierto nivel cultural que, tal vez, de otra forma les fuera difícil obtener.

Incluso es válido asegurar que en esta concurrencia [es decir los jóvenes que no han podido alcanzar los estudios de bachillerato] el progresivo conocimiento del lenguaje cinematográfico podría suplir a la cultura, pues a través de la sintaxis y la plástica de las imágenes, los jóvenes espectadores llegarían a descubrir ciertos elementos estéticos que forman la estructura de las otras artes ${ }^{41}$.

Sea como sea, la conclusión es que la enseñanza del audiovisual se debe empezar desde edad temprana. La adolescencia, con el despertar de los sentidos y de la vida, junto a su connatural deseo de conocer cosas nuevas e impenitente curiosidad, parece la edad más adecuada.

Es muy deseable que la formación del futuro público de cine se inicie en la adolescencia. Fijémonos en los adultos que tienen ocasión de seguir con regularidad las sesiones de un cine-club serio, donde pueden adquirir el gusto del verdadero cine. Advirtamos, empero, que las más veces un obstáculo de extensa gravedad se opone a una fecunda asimilación de la cultura cinematográfica: no es otro que la misma edad adulta. Ante todo y sobre todo, lo que vamos a decir no es una mera especulación; cualquiera puede comprobarlo en sí mismo o en sus prójimos: la cultura y la orientación impuestas al común de los hombres han venido a producir un anquilosamiento, como una esclerosis en ciertos resortes inutilizados de su espíritu. Para concretar, diremos que el carácter por demás preciso de la cultura literaria ha infundido una escala de valores muy particulares a los espectadores. (...)

No hay que esperar, pues, a que sea demasiado tarde para que los espectadores se inicien en el juicio de un "film"; lo factible es aprovechar la ductilidad de los jóvenes, capaces de adaptar su atención a una materia nueva y someterse a las directrices de un mayor; con la máxima urgencia posible, llamemos la atención de los jóvenes sobre la existencia estética y espiritualidad del cine; desde esa temprana edad, obtengamos de ellos un 
rigor y una exigencia que en el futuro les permitan boicotear, incluso con la mera abstención, al cine depravado y mediocre, favoreciendo, en cambio, el desarrollo del séptimo arte hasta donde puedan ${ }^{42}$.

\section{Referencias}

AGEL, Henri con Geneviève Agel: Manual de iniciación cinematográfica, Madrid, Rialp, 1958 (3ed. 1965).

AGEL, Henri y AYFRE, Amédée: Cine y personalidad, Madrid, Rialp, 1963, p. 74.

AGEL, Henri: ¿El cine tiene alma? Madrid, Rialp, 1958, pp. 123-124 (la cita dentro del texto es de H. Gouhier, sic).

AGEL, Henri: "El cine, nueva dimensión" en VV.AA. Cine, educadores y educandos, Madrid, Sociedad de Educación Atenas, 1961, p. 18.

AGEL, Henri: El cine y lo sagrado, Madrid, Rialp, 1960, p. 109.

AGEL, Henri: El cine. Bilbao, Desclée de Brouwer, 1957, p. 137.

AGEL, Henri: Le cinéma ses diverses méthodes d'enseignement, Friburgo, Ed. Université du Fribourg, 1978.

AGEL, Henri: Manual de iniciación cinematográfica, Madrid, Rialp, 1958, p. 35.

ANDREW, Dudley J.: Las principales teorías cinematográficas, Madrid, Rialp (2a ed.aumentada; $1^{\mathrm{a}}$ ed. en Barcelona, Gustavo Gili, 1978). p. 295.

AGEL, Henri: "La victoire sur la passivité" en HAHN, George (Ed.): Cinéma univers de l'absence? Le sort de la personne dans l'oeuvre filmique, París, P.U.F., 1960, pp. 56-67.

ZURIAN Francisco A.: "Entrevista con Henri Agel: Por una teoría del cine" en FilmHistoria, Vol. I, n 1, 1991, p. 40.

STEINER, George: Presencias reales. ¿Hay algo en lo que decimos?, Barcelona, Destino, 1991, p. 29.

VV.AA. Cine, educadores y educandos, Madrid, Sociedad de Educación Atenas, 1961

WOLLEN, Peter: Signs and Meaning in the Cinema, Londres, Thames and Hudson, p. 164.

ZURIAN, Francisco A.: "Entrevista con Henri Agel: Por una teoría del cine" en FilmHistoria, Vol. I, nº 1, 1991, p. 41. 
Francisco A. Zurian

ZURIAN, Francisco A.: "Lo real, lo imaginario y lo insinuado. Notas en torno a Henri Agel" en Quaderns de Filosofia i Ciència, nn. 13-14, 1988, p. 172. 